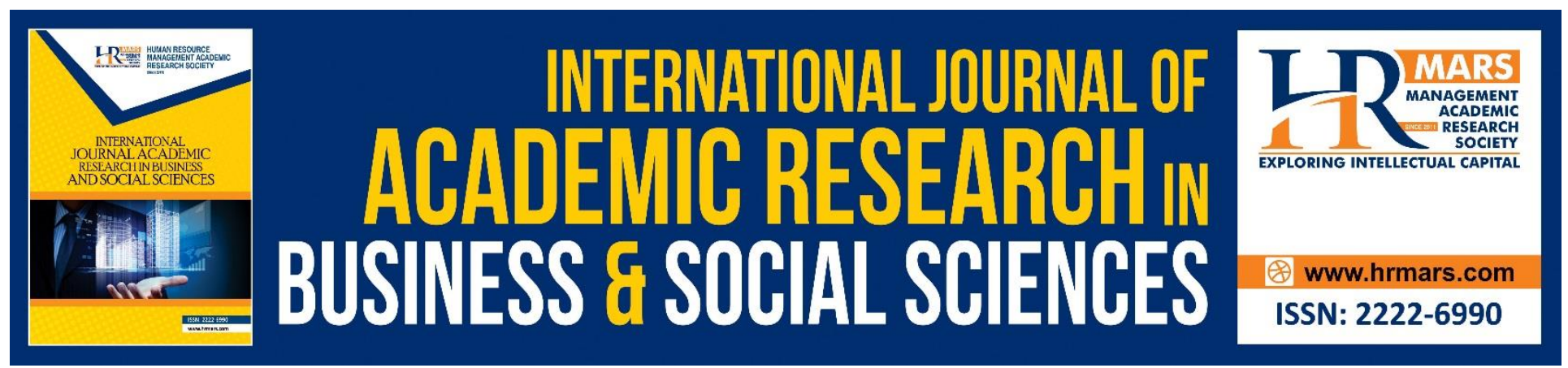

\title{
Job demands and Job Resources: A study of nurses at a General Hospital in Malaysia
}

\author{
Nurazuwin Kursiah Mat Tahir, Norashikin Hussein
}

To Link this Article: http://dx.doi.org/10.6007/IJARBSS/v8-i11/5561

DOI: $10.6007 /$ IJARBSS/v8-i11/5561

Received: 07 Oct 2018, Revised: 28 Nov 2018, Accepted: 04 Dec 2018

Published Online: 09 Dec 2018

In-Text Citation: (Tahir \& Hussein, 2018)

To Cite this Article: Tahir, N. K. M., \& Hussein, N. (2018). Job demands and Job Resources: A study of nurses at a General Hospital in Malaysia. International Journal of Academic Research in Business and Social Sciences, 8(11), 1971-1983.

\section{Copyright: (C) 2018 The Author(s)}

Published by Human Resource Management Academic Research Society (www.hrmars.com)

This article is published under the Creative Commons Attribution (CC BY 4.0) license. Anyone may reproduce, distribute, translate and create derivative works of this article (for both commercial and non-commercial purposes), subject to full attribution to the original publication and authors. The full terms of this license may be seen

at: http://creativecommons.org/licences/by/4.0/legalcode

\section{Vol. 8, No. 11, 2018, Pg. 1971 - 1983}

Full Terms \& Conditions of access and use can be found at http://hrmars.com/index.php/pages/detail/publication-ethics 


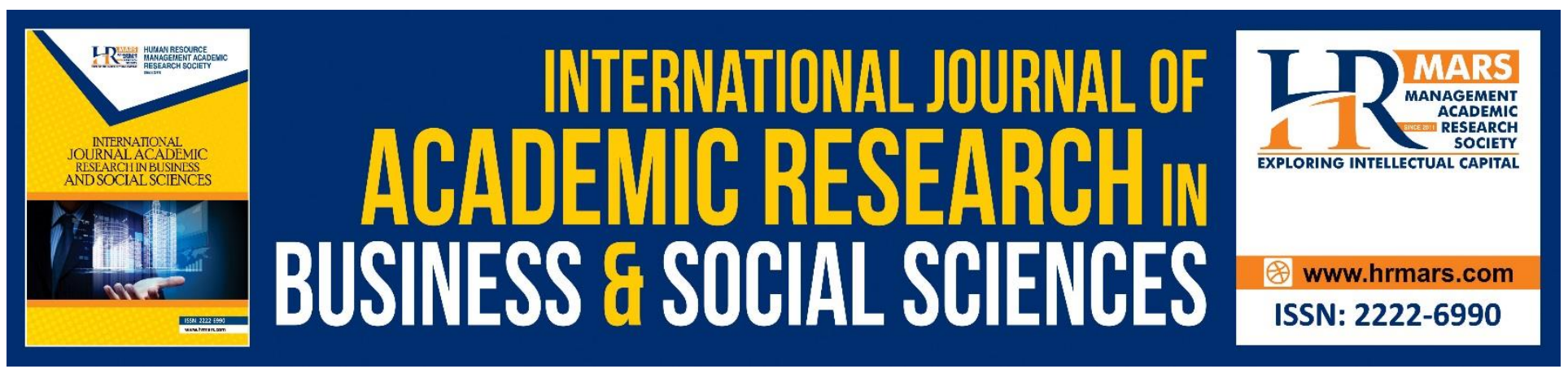

\title{
Job demands and Job Resources: A study of nurses at a General Hospital in Malaysia
}

\author{
Nurazuwin Kursiah Mat Tahir ${ }^{1}$, Norashikin Hussein ${ }^{2}$ \\ ${ }^{1}$ Faculty of Business and Management, Universiti Teknologi MARA (UiTM) Shah Alam, Selangor, \\ Malaysia \\ ${ }^{2}$ Faculty of Business and Management, Universiti Teknologi MARA (UiTM) Shah Alam, Selangor, \\ Malaysia.
}

\begin{abstract}
Background: The nursing profession is stressful since they have to deal with an extensive number of patients daily. Therefore, the Job Demands-Resources (JD-R) model has been proposed as the fundamental model in this study. The model is important in describing the job demands and job resources among nurses, specifically in Malaysia. Additionally, the job demands and job resources reflect their performance and service outcome. Therefore, this paper extends knowledge by emphasizing on the descriptive analysis basis of job demands and job resources among staff nurses of a general hospital in Malaysia. 60 staff nurses were randomly selected from a general hospital, which is located in Peninsular Malaysia who were involved to determine the level of their job demands and job resources. Objective: This study is used to determine the level of job demands and job resources among staff nurses in Malaysia. Results: Based on overall means, the study found that the nurses received a high level of physical and mental demands. However, the result indicated that they received a low level of autonomy and performance feedback from their respective colleagues and superiors. Additionally, they also received a moderate level of social support from the same colleagues and superiors. Conclusion: The present study is used to provide the updated review of descriptive analysis basis of job demands and job resources among nurses of a general hospital in Malaysia as well as to fill the literature gap.
\end{abstract}

Keywords: Job demands, Job resources, Nurse

\section{INTRODUCTION}

The topic of Job Demands-Resources (JD-R) model has gained high popularity in occupational stress among the researchers for the past few decades (Hu, Schaufeli, and Taris, 2013). The model assumes that the balanced combination of both job demands (negative) and job resources (positive) result in the employees' well-being (Hu et al., 2013). Job demands are generally concerned about any job aspects that can cause job stress, which typically generate the negative outcomes (Han, 2016). In 
INTERNATIONAL JOURNAL OF ACADEMIC RESEARCH IN BUSINESS AND SOCIAL SCIENCES

Vol. 8, No. 11, Nov, 2018, E-ISSN: 2222-6990 @ 2018 HRMARS

contrast, job resources are generally concerned about any job aspects that boost individual's motivation to cope with the job demands, which typically generate positive outcome (Han, 2016). There are a lot of studies concerning on Job Demands-Resources (JD-R) model among employees in various organizations including manufacturing sector, administrative sector, healthcare sector (Brauchli, Jenny, Füllemann, and Bauer, 2015) and education sector (van den Tooren and de Jong, 2014). In the healthcare sector, there are studies that emphasized on both job demands and job resources among nurses in various countries including Korea (Han, 2016), New Zealand (Kimber \& Gardner, 2016) and China (Hu et al., 2013).

Nursing is a service profession within the healthcare sector. In general, nurses play a significant role in satisfying the patients to cope with illness by providing high-quality services (Han, 2016; Sabil, Abu, Kasuma, \& Lizzan, 2016). However, previous literature highlighted that the nursing profession is stressful (Long, Kowang, Ping, and Muthuveloo, 2014; Sabil et al., 2016). One of the core issues that caused them to become stressful is excessive workload which requires their emotional, mental and physical demands, especially in the hospitals in which they have to deal with the extensive number of patients every day (Long et al., 2014; Sabil et al., 2016). Therefore, nurses are one of the workforce who are extremely affected by the issue of excessive workload. The Ministry of Health Malaysia (2016) reported that to date, the nurse-to-patient population ratio is recorded as 1:325 which is far below than the recommended ratio of $1: 200$ by the World Health Organization. Heavy workload requires some nurses to perform their tasks within longer working hours in a day which affect their work responsibilities and also commitment at home (Sabil et al., 2016). In fact, Sabil et al. (2016) found that workload is the most important factor that leads to work-family conflict. These situations question how do the nurses deal with their challenging work every day and the slightest mistake can prompt medication error and careless cases (Johari, Shamsuddin, Idris, and Hussin, 2013).

In a study of 8,620 registered nurses (RNs) in Sweden, it was found that 29.8 percent of nurses were emotionally exhausted (Leineweber, Westerlund, Chungkham, \& Lindqvist, 2014). Similarly, in a study of 676 nursing professionals in Andalusian Health Service, Spain, it was found that 25 percent of the respondents reached the high level of emotional exhaustion (Fuente et al., 2015). Additionally, Mokhtar, Shikieri, Taha and Rayan (2016) found that the level of occupational stressors of most nurses in Pediatric and Neonatal Intensive Care Units (NICU) were reported as above average. The above average of occupational stressors was including relationship problems at work and dealing with patients. Meanwhile, insufficient equipment and unit's atmosphere were reported as the high level of occupational stressors (Mokhtar et al., 2016).

Thus, the complexity of their nature of work contributing to high level of pressures which may affect their service outcome as well as personal life (Sabil et al., 2016). In details, the challenging of nursing profession requires them to cope with a high degree of emotional, physical and mental demands (Donoso, Demerouti, Hernandez, Moreno-Jimenez, \& Cobo, 2015; Sabil et al., 2016). These demands are associated with their work outcome and personal life (Sabil et al., 2016). These situations indicate that nurses are facing challenges of job demands. Nonetheless, the job demands can be managed by having great job resources (Donoso et al., 2015).

Due to the issues arise, job resources are required to meet the desired outcome of work and personal life. Unfortunately, previous literature stated that nurses often have lack of job resources to cope with the availability of job demands (Demerouti, Bakker, Nachreiner, and Schaufeli, 2000; Long et al., 
2014) including lack of autonomy (Sarkoohijabalbarezi, Ghodousi, and Davaridolatabadi, 2017), lack of social support from colleagues and poor performance feedback (Long et al., 2014). Therefore, both job demands and job resources serve as the important elements, especially among nurses to achieve their desired goals.

The Job Demands-Resources (JD-R) model has been proposed as the fundamental model in the present study. This is due to the fact that the model is validated among employees who primarily deal with people which are the nurses (Demerouti, Bakker, Nachreiner, \& Schaufeli, 2001). Significantly, the model is important to describe the level of job demands and job resources among nurses, specifically in Malaysia. Additionally, there are a lot of studies that emphasize on the relationship between Job Demands-Resources (JD-R) model with the organizational or individual outcome such as job engagement (Brauchli et al., 2015; Han, 2016), burnout (Hu et al., 2013) and intention to leave (Hoonakker, Carayon, and Korunka, 2013; Kimber and Gardner, 2016). However, contrary to most studies on the Job Demands-Resources (JD-R) model, the research gap exists where there are very few studies which emphasize on descriptive analysis basis of job demands and job resources, especially among staff nurses in Malaysia. Hence, the main contribution of this study is the descriptive analysis basis on job demands and job resources which are conducted among staff nurses in Malaysia. Therefore, this study attempts to determine: (i) the level of job demands (emotional demands, physical demands and mental demands) and (ii) the level of job resources (autonomy, social support and performance feedback) among staff nurses in Malaysia.

\section{Literature review}

Job Demands-Resources (JD-R) Model: The Job Demands-Resources (JD-R) model is originally developed by (Demerouti et al., 2001). It consists of two general categories of work environment characteristics which include job demands and job resources (Demerouti et al., 2001). Previous literature often defines job demands as any job aspects that require physical or psychological effort and are therefore associated with certain physiological or psychological costs (Demerouti and Bakker, 2011). Job demands are also known as job stressors such as time pressure and heavy workload (Demerouti et al., 2001). In contrast, job resources have often been defined as any job aspects that have the motivational potential to attain the organization's goals, deal with the job demands and stimulate personal growth and development such as performance feedback (Demerouti and Bakker, 2011).

Additionally, Job Demands-Resources (JD-R) model consists of two underlying psychological processes (van den Tooren \& de Jong, 2014). Firstly, the job demands underlying in health impairment processes (Van den Tooren and de Jong, 2014). This is due to the fact that high level of job demands are usually caused in unfavourable ways which can lead to the occurrence of strain (Bakker, 2015), exhaustion, energy depletion and health problems (van den Tooren \& de Jong, 2014). Furthermore, high level of job demands can affect the individual and they are unable to attain the work-related goals. This situation occurs when there is a lack of job resources (Bakker, 2015). However, high level of job demands do not necessarily result in negative outcomes such as exhaustion (Kimber \& Gardner, 2016). Previous literature identified job demands which are relevant to the nursing profession including workload, the complexity of tasks and emotional demands (Kimber and Gardner, 2016). 
In contrast, the sufficiency of job resources typically encourage the favourable effects which drive the employees to perform well in their job (Bakker, 2015). The second process, job resources underlying in motivational processes (van den Tooren and de Jong, 2014). It plays a motivational role (van den Tooren and de Jong, 2014). High level of job resources drive the employees to be more capable to deal with the job demands (van den Tooren and de Jong, 2014). Thus, it indicates that the sufficiency of job resources can boost the employee's motivation and commitment to attain the desired outcome. Previous literature identified the job resources which is essential for nurses including recognition at the workplace, role clarity and opportunities of skills development (Kimber and Gardner, 2016).

Based on the recent studies, Kimber and Gardner (2016) found that the job demands have a positive relationship with emotional exhaustion, but there was a negative relationship between job resources and emotional exhaustion among veterinary nurses. Besides, Hu, Schaufeli and Taris (2016) found that the job demands have a strong positive and significant relationship with burnout, but have a negative relationship with the engagement among nurses in China. Meanwhile, the job resources have a positive and significant relationship with organizational commitment (Hu et al., 2016). Thus, it shows that the Job Demands-Resources (JD-R) model may lead to both positive and negative outcome.

Initially, Demerouti et al. (2001) reveals physical workload, time pressure, recipient contact, physical environment and working on shifts as the dimensions of job demands. Meanwhile, feedback, rewards, job control, participation, job security and supervisor support are all acting as the dimensions of job resources (Demerouti et al., 2001). However, Bakker and Demerouti (2007) expand the model by proposing emotional demands, physical demands and mental demands as the dimensions of job demands. Meanwhile, the dimensions of job resources include autonomy, social support and performance feedback (Bakker and Demerouti, 2007).

Based on the recent studies, Kimber and Gardner (2016) who studied among veterinary nurses have recommended emotional demands, workload and complex tasks as the dimensions of job demands. The dimensions of job resources are potential for development, job predictability and recognition (Kimber and Gardner, 2016). Besides, Hu et al. (2013) who studied on nurses in China have suggested that workload, emotional demands, physical demands, mental demands and interpersonal conflict as job demands' dimensions. The dimensions of job resources include job control, task clarity and opportunities for learning and development (Hu et al., 2013). Thus, based on previous literature, it shows that there are various dimensions of job demands and job resources used, particularly among nurses.

As excessive workload that requires emotional, physical and mental demands which are followed by poor performance feedback (Long et al., 2014), lack of autonomy (Sarkoohijabalbarezi et al., 2017) and social support (Long et al., 2014) among the nurses in Malaysia, the present study tend to adopt the Job Demands-Resources (JD-R) model which was developed by Bakker and Demerouti (2007) as the main theoretical framework. Additionally, the descriptive analysis basis on job demands and job resources through the Job Demands-Resources (JD-R) model which developed by Bakker and Demerouti (2007) seems to be scarce. Moreover, the dimensions used are the most relevant to the issues arise among nurses, recently. In fact, the dimensions used are largely depended on the focal job (Demerouti and Bakker, 2011). 
The dimensions of job demands in this study consisted of emotional demands, physical demands and mental demands. In details, emotional demands refer to dealing with strong inner feelings such as anger and frustration at work (Gabel-Shemueli, Dolan, and Ceretti, 2014). Physical demands can be described as dealing with the physical effort such as arm movement (Ruitenburg, Frings-Dresen, and Sluiter, 2013). Meanwhile, mental demands can be defined as dealing with mental effort in carrying out the duties (Demerouti and Bakker, 2011) such as remembering patient's information.

The dimensions of job resources in this study consisted of autonomy, social support and performance. Autonomy refers to the state of freedom on how to implement the task given (GabelShemueli et al., 2014). Social support means the state of support and assistance received from other people in the organization such as supervisory support (Lambert, Minor, Wells, and Hogan, 2015). Meanwhile, performance feedback can be described as the state of information received on how well they carry out the tasks given (Demerouti and Bakker, 2011).

\section{METHODOLOGY}

Before conducting the pilot test in a general hospital in Peninsular Malaysia, the present study was first registered through National Medical Research Register (NMRR) website to obtain the ethical approval from Medical Research and Ethics Committee (MREC). The ethical approval from MREC is important when conducting the present study since the respondents of the study involved nurses working at a general hospital, which is under the Ministry of Health Malaysia.

The present study is a quantitative research which use questionnaires to collect data. The questionnaires were distributed to a general hospital upon obtaining the ethical approval from MREC. A total of 60 staff nurses of Grade U29 at a general hospital in Peninsular Malaysia were included in the sample as a pilot test.

All items of job demands and job resources in the present study were measured using medium-length Copenhagen Psychosocial Questionnaire (COPSOQ) which is adopted from Kristensen, Hannerz, Hogh and Borg (2005). The questionnaires are based on a seven-point Likert-scales, which comprises of 21 items to measure the variables that include emotional demands, physical demands, mental demands, autonomy, social support and performance feedback. IBM SPSS Statistic version 23 was used for statistical analysis.

\section{RESULTS AND DISCUSSION}

Demographics: Out of 60 staff nurses, $n=49(82 \%)$ were female. Majority participants' age were ranged from 26 to 35 years old, with 67 percent $(n=40)$. Similar to their marital status, 67 percent ( $n$ $=40$ ) of them are married. In addition, 77 percent $(n=46)$ of respondents are scheduled to work in shifts. Only 23 percent $(n=14)$ of them worked in non-shift schedule.

Reliability: Table 1 presents the summary of internal consistency reliability for each construct used in this study. The Cronbach's alpha coefficient were showed as follows: 
INTERNATIONAL JOURNAL OF ACADEMIC RESEARCH IN BUSINESS AND SOCIAL SCIENCES

Vol. 8, No. 11, Nov, 2018, E-ISSN: 2222-6990 @ 2018 HRMARS

Table 1: Reliability Analysis

\begin{tabular}{|l|l|l|}
\hline Construct & $\begin{array}{l}\text { No. of } \\
\text { item }\end{array}$ & $\begin{array}{l}\text { Cronbach's } \\
\text { Alpha }\end{array}$ \\
\hline $\begin{array}{l}\text { Emotional } \\
\text { demands }\end{array}$ & 3 & 0.84 \\
\hline Physical demands & 4 & 0.94 \\
\hline Mental demands & 4 & 0.81 \\
\hline Autonomy & 4 & 0.57 \\
\hline Social support & 4 & 0.76 \\
\hline $\begin{array}{l}\text { Performance } \\
\text { feedback }\end{array}$ & 2 & 0.71 \\
\hline
\end{tabular}

Overall, Table 1 indicated that most of the research constructs have high reliability with the Cronbach's Alpha exceed 0.7 (Nunally, 1978) except for autonomy which has a low reliability of 0.57. However, the value of Cronbach's alpha, which is more than 0.5 considered acceptable (Nunally, 1978).

Descriptive Analysis: The descriptive analysis examined the percentage of agreement based on Likert scale which ranged from (4) to (7). Besides, this study examined the means and standard deviation for every item and also overall means for each variable which are all presented in the tables below. The job demands of present study consists of three dimensions which include emotional demands, physical demands and mental demands. Meanwhile, the dimensions of job resources, including autonomy, social support and performance feedback.

Table 2: Descriptive analysis of emotional demands

\begin{tabular}{|l|l|l|l|}
\hline Emotional demands (Overall means: 3.73) \\
\hline Item & $\begin{array}{l}\text { Percentage of } \\
\text { agreement (\%) }\end{array}$ & Mean & SD \\
\hline $\begin{array}{l}\text { *My work puts me in an } \\
\text { emotionally disturbing } \\
\text { situation. }\end{array}$ & 33.3 & 3.75 & 1.601 \\
\hline $\begin{array}{l}\text { *My work is emotionally } \\
\text { demanding. }\end{array}$ & 38.3 & 4.12 & 1.776 \\
\hline $\begin{array}{l}\text { *I get emotionally involved } \\
\text { during work. }\end{array}$ & 26.7 & 3.32 & 1.836 \\
\hline
\end{tabular}

First, emotional demands consist of three items. The scale was rated on a seven-point Likert scale which ranged from never (1) to always (7) for the first item and ranged between not at all (1) and to a very large extent (7) for another two items, respectively. In overall, the means of emotional demands were 3.73. It shows that occasionally, they felt a bit emotional towards their job. In detail, the results found that only 33.3 percent of respondents were experiencing the emotionally disturbing situation. 38.3 percent of respondents felt their work was emotionally demanding and only 26.7 
INTERNATIONAL JOURNAL OF ACADEMIC RESEARCH IN BUSINESS AND SOCIAL SCIENCES

Vol. 8, No. 11, Nov, 2018, E-ISSN: 2222-6990 @ 2018 HRMARS

percent got emotionally involved during work. The results show that their level of emotional demands are considered low.

Table 3: Descriptive analysis of physical demands

\begin{tabular}{|c|c|c|c|}
\hline \multicolumn{4}{|c|}{ Physical demands (Overall means: 5.88 ) } \\
\hline Item & $\begin{array}{l}\text { Percentage of } \\
\text { agreement (\%) }\end{array}$ & Mean & SD \\
\hline $\begin{array}{l}\text { My work requires me to } \\
\text { have very clear and precise } \\
\text { eyesight. }\end{array}$ & 85.0 & 5.70 & 1.488 \\
\hline $\begin{array}{l}\text { My work requires me to } \\
\text { have control over my } \\
\text { movements. }\end{array}$ & 83.3 & 5.77 & 1.651 \\
\hline $\begin{array}{l}\text { My work demands my } \\
\text { constant attention. }\end{array}$ & 90.0 & 6.02 & 1.214 \\
\hline $\begin{array}{l}\text { My work requires a high } \\
\text { level of precision. }\end{array}$ & 90.0 & 6.03 & 1.275 \\
\hline
\end{tabular}

Next, physical demands consists of four items. The scale of physical demands was rated on a sevenpoint Likert scale which ranged from never (1) to always (7). In overall, the means of physical demands were 5.88. It shows that the nursing profession usually requires the high level of physical demands to serve patients such as lifting the patient from one bed to another bed and also need precise eyesight to insert the needle into the nerves of the patient's body. Additionally, Table 3 shows that more than 80 percent of respondents experienced the high levels of physical demands which include precise eyesight, controlled body movement, constant attention and precision.

Table 4: Descriptive analysis of mental demands

\begin{tabular}{|l|l|l|l|}
\hline Mental demands (Overall means: 5.32) \\
\hline Item & $\begin{array}{l}\text { Percentage of } \\
\text { agreement (\%) }\end{array}$ & Mean & SD \\
\hline $\begin{array}{l}\text { I have to focus my eyes on } \\
\text { so many things while at } \\
\text { work. }\end{array}$ & 80.0 & 5.68 & 1.546 \\
\hline $\begin{array}{l}\text { My work requires me to } \\
\text { remember many things. }\end{array}$ & 83.3 & 5.82 & 1.255 \\
\hline $\begin{array}{l}\text { My work demands that I am } \\
\text { good at coming up with } \\
\text { new ideas. }\end{array}$ & 78.3 & 5.40 & 1.392 \\
\hline $\begin{array}{l}\text { My work requires me to } \\
\text { make difficult decisions. }\end{array}$ & 53.3 & 4.38 & 1.738 \\
\hline
\end{tabular}


Mental demands consist of four items. The scale of mental demands was rated on a seven-point Likert scale which ranged from never (1) to always (7) as the response option. In overall, the means of mental demands were 5.32. The results indicated that nurses usually required a high level of mental demands which include eye focusing, remembering many things, coming up with new ideas and making difficult decisions. In fact, 80 percent and 83.3 percent of respondents were always required to focus and remember so many things, respectively. Additionally, more than half of the respondents (78.3\% and 53.3\%) were always required to brainstorm new ideas and make difficult decisions, respectively. Thus, the result shows that their level of mental demands are considered high.

Table 5: Descriptive Analysis of Autonomy

\begin{tabular}{|l|l|l|l|}
\hline \multicolumn{4}{|l|}{ Autonomy (Overall means: 3.03) } \\
\hline Item & $\begin{array}{l}\text { Percentage of } \\
\text { agreement (\%) }\end{array}$ & Mean & SD \\
\hline $\begin{array}{l}\text { I can decide when to take } \\
\text { a break. }\end{array}$ & 60.0 & 4.57 & 1.651 \\
\hline $\begin{array}{l}\text { I can take as little or as } \\
\text { many leaves as I wish. }\end{array}$ & 26.7 & 3.32 & 1.600 \\
\hline $\begin{array}{l}\text { I can leave my work to } \\
\text { have a chat with a } \\
\text { colleague. }\end{array}$ & 8.3 & 2.37 & 1.327 \\
\hline $\begin{array}{l}\text { If I have some personal } \\
\text { duties, it is possible for me } \\
\text { to leave my work for half } \\
\text { an hour without } \\
\text { permission from my } \\
\text { superior. }\end{array}$ & 10.0 & 1.508 \\
\hline
\end{tabular}

Next, in terms of job resources, the scales were all rated on a seven-point Likert scale which ranged from never (1) to always (7). Firstly, autonomy consists of four items. In overall, the means of autonomy were reported as 3.03. It shows that nurses in Malaysia received a low level of autonomy. Table 5 shows that only 8.3 percent of the respondents leave their work to have a chat with colleagues and 10 percent of them leave their work for half an hour to fulfill their personal duties. However, 60 percent of the respondents can decide when to take a break and only 26.7 percent of them can take how many leaves as they wish. The results concluded that the issue of excessive workload limits their degree of freedom to implement the tasks given. 
INTERNATIONAL JOURNAL OF ACADEMIC RESEARCH IN BUSINESS AND SOCIAL SCIENCES

Vol. 8, No. 11, Nov, 2018, E-ISSN: 2222-6990 (C) 2018 HRMARS

Table 6: Descriptive Analysis of Social Support

\begin{tabular}{|l|l|l|l|}
\hline \multicolumn{3}{|l|}{ Social support (Overall means: 4.24) } \\
\hline Item & $\begin{array}{l}\text { Percentage of } \\
\text { agreement (\%) }\end{array}$ & Mean & SD \\
\hline $\begin{array}{l}\text { I often get help and } \\
\text { support from my } \\
\text { colleagues. }\end{array}$ & 4.70 & 1.381 \\
\hline $\begin{array}{l}\text { My colleagues are willing } \\
\text { to listen to my work- } \\
\text { related problems. }\end{array}$ & 4.58 & 1.430 \\
\hline $\begin{array}{l}\text { I often get help and } \\
\text { support from my } \\
\text { immediate superior. }\end{array}$ & 38.3 & 3.97 & 1.426 \\
\hline $\begin{array}{l}\text { My immediate superior is } \\
\text { willing to listen to my } \\
\text { work-related problems. }\end{array}$ & 30.0 & 3.70 & 1.344 \\
\hline
\end{tabular}

Besides, social support consists of four items. The overall means of social support were 4.24. Thus, in overall, the respondents received a moderate level of social support. The result indicated that they frequently received help and support from colleagues and superiors. In details, Table 5 shows that less than half of respondents (38.3\% and $30 \%$ ) received superiors' support and listened to their workrelated problems, respectively. The results concluded that the superiors were unable to provide help, support and listen to their work-related problems, which may be due to their limited time available. However, more than 50 percent of the respondents ( $56.7 \%$ and $51.7 \%$, respectively) received support from their colleagues.

Table 7: Descriptive Analysis of Performance Feedback

\begin{tabular}{|l|l|l|l|}
\hline \multicolumn{3}{|l|}{ Performance feedback (Overall means: 3.98) } \\
\hline Item & $\begin{array}{l}\text { Percentage of } \\
\text { agreement (\%) }\end{array}$ & Mean & SD \\
\hline $\begin{array}{l}\text { My superior often talks to } \\
\text { me on how I carry out my } \\
\text { tasks. }\end{array}$ & 33.3 & 3.92 & 1.279 \\
\hline $\begin{array}{l}\text { My colleagues often talk } \\
\text { to me on how I carry out } \\
\text { my tasks. }\end{array}$ & 40.0 & 4.03 & 1.235 \\
\hline
\end{tabular}

Meanwhile, performance feedback consists of only two items. The overall means of performance feedback were 3.98. It means that they occasionally received feedback from superiors and colleagues about how well they carried out the tasks given. Thus, it shows that they received a low level of performance feedback from colleagues and superiors. Less than half of the respondents (33.3\% and 
$40 \%$, respectively) received the colleagues and superiors feedback on how well they carried out the tasks given. The situation occurred may be due to the workload which makes them have very limited time to provide feedback to each other.

\section{CONCLUSION}

In general, low level of job demands with a sufficiency of job resources received among workers lead to better work outcomes. Thus, the issues which relate to the employee's job demands and job resources are essential in every organization, especially among employees who work in the service sector, including nurses. Hence, the present study shows that job demands and job resources are deemed as the relevant elements in determining the work outcome of nurses. This is due to the fact that, nurses need to have sufficient job resources to serve the extensive number of patients daily which require their emotional, physical and mental demands. The present study is significant in formulating guidelines and policies in regards to the job demands and job resources of nurses, especially in the hospital. This is vital to indicate their quality of life. Besides, the present study is used to fill the literature gap on the limited evidence of descriptive analysis of Job Demands-Resources (JD-R) model which were conducted among nurses of general hospitals in Malaysia.

\section{ACKNOWLEDGEMENT}

The authors would like to gratefully acknowledge research support under 'Geran Inisiatif Penyeliaan (GIP)' (600-IRMI/MyRA 5/3/GIP (008/2017)), administered and funded by Research Management Centre (RMC) Institute of Research Management and Innovation (IRMI), Universiti Teknologi MARA, Shah Alam, Malaysia.

\section{REFERENCES}

Bakker, A. B. (2015). Towards a multilevel approach of employee well-being. European Journal of Work and Organizational Psychology, 24(6), 839-843. doi: 10.1080/1359432X.2015.1071423

Bakker, A. B., \& Demerouti, E. (2007). The Job Demands Resources model: State of the art. Journal of Managerial Psychology, 22(3), 309-328. doi: 10.1108/02683940710733115

Brauchli, R., Jenny, G. J., Füllemann, D., \& Bauer, G. F. (2015). Towards a Job Demands-Resources Health Model-empirical testing with generalizable indicators of job demands, job resources and comprehensive health outcomes. BioMed Research International, 2015, 1-12. Doi: 10.1155/2015/959621

Demerouti, E., \& Bakker, A. B. (2011). The Job Demands-Resources model: Challenges for future research. SA Journal of Industrial Psychology, 37(2), 1-9. doi: 10.4102/sajip.v37i2.974

Demerouti, E., Bakker, A. B., Nachreiner, F., \& Schaufeli, W. B. (2001). The Job Demands-Resources Model of Burnout. Journal of Applied Psychology, 86(3), 499-512.

Demerouti, E., Bakker, A., Nachreiner, F., \& Schaufeli, W. B. (2000). A model of burnout and life satisfaction amongst nurses. Journal of Advanced Nursing, 32(2), 454-464.

Donoso, L. M. B., Demerouti, E., Hernandez, E. G., Moreno-Jimenez, B., \& Cobo, I. C. (2015). Positive benefits of caring on nurses' motivation and well-being: A diary study about the role of emotional regulation abilities at work. International Journal of Nursing Studies, 52(4), 804-816. doi: 10.1016/j.ijnurstu.2015.01.002 
INTERNATIONAL JOURNAL OF ACADEMIC RESEARCH IN BUSINESS AND SOCIAL SCIENCES

Vol. 8, No. 11, Nov, 2018, E-ISSN: 2222-6990 @ 2018 HRMARS

Fuente, G. A. C. D. la, Vargas, C., Luis, C. S., Garcia, I., Canadas, G. R., \& Fuente, E. I. D. la. (2015). Risk factors and prevalence of burnout syndrome in the nursing profession. International Journal of Nursing Studies, 52, 240-249. doi: 10.1016/j.ijnurstu.2014.07.001

Gabel-Shemueli, R., Dolan, S. L., \& Ceretti, S. (2014). Being engaged: The multiple interactions between job demands and job resources and its impact on nurses engagement. International Journal of Nursing, 3(32), 17-32.

Han, J. W. (2016). Effect of nurses' job demands and job resources on work engagement based on JDR model. Advanced Science and Technology Letters, 128, 14-17.

Hoonakker, P., Carayon, P., \& Korunka, C. (2013). Using the Job-Demands-Resources model to predict turnover in the information technology workforce - General effects and gender differences. Horizons of Psychology, 22, 51-65. doi: 10.20419/2013.22.373

Hu, Q., Schaufeli, W. B., \& Taris, T. W. (2013). Does equity mediate the effects of Job Demands and Job Resources on work outcomes?: An extension of the Job Demands-Resources Model. Career Development International, 18(4), 357-376. doi: 10.1108/CDI-12-2012-0126

Hu, Q., Schaufeli, W. B., \& Taris, T. W. (2016). Extending the job demands-resources model with guanxi exchange. Journal of Managerial P, 31(1), 127-140. doi: 10.1108/JMP-04-2013-0102

Johari, H., Shamsuddin, F., Idris, N., \& Hussin, A. (2013). Medication errors among nurses in government hospital. IOSR Journal of Nursing and Health Science, 1(2), 18-23. Retrieved from http://iosrjournals.org/iosr-jnhs/papers/vol1-issue2/D0121823.pdf?id=1631

Kimber, S., \& Gardner, D. H. (2016). Relationships between workplace well-being , job demands and resources in a sample of veterinary nurses in New Zealand. New Zealand Veterinary Journal. Doi: 10.1080/00480169.2016.1164092

Kristensen, T. S., Hannerz, H., Hogh, A., \& Borg, V. (2005). The Copenhagen Psychosocial Questionnaire: A tool for the assessment and improvement of the psychosocial work environment. Scandavanian Journal of Work, Environment \& Health, 31(6), 438-449. doi: 10.5271/sjweh.948

Lambert, E. G., Minor, K. I., Wells, J. B., \& Hogan, N. L. (2015). Social support's relationship to correctional staff job stress, job involvement, job satisfaction and organizational commitment. The Social Science Journal, 53(1), 1-11. doi: 10.1016/j.soscij.2015.10.001

Leineweber, C., Westerlund, H., Chungkham, H. S., \& Lindqvist, R. (2014). Nurses' practice environment and work-family conflict in relation to burn out : A multilevel modelling approach. PLOS ONE, 9(5), 1-9. Doi: 10.1371/journal.pone.0096991

Long, C. S., Kowang, T. O., Ping, T. A., \& Muthuveloo, R. (2014). Investigation on the impact of job stressors on nurses in Malaysia. Asian Social Science, 10(4), 67-77. doi: 10.5539/ass.v10n4p67

Ministry of Health Malaysia. (2016). Health Facts 2016, 2015-2016.

Mokhtar, K., Shikieri, A. El, Taha, E. M., \& Rayan, A. (2016). The relationship between occupational stressors and performance amongst nurses working in Pediatric and Intensive Care Units. American Journal of Nursing Research, 4(2), 34-40. Doi: 10.12691/ajnr-4-2-2

Nunally, J. C. (1978). Psychometric theory. New York: Mcgraw-Hill.

Ruitenburg, M. M., Frings-Dresen, M. H. W., \& Sluiter, J. K. (2013). Physical job demands and related health complaints among surgeons. International Archives of Occupational and Environmental Health, 86(3), 271-279. Doi: 10.1007/s00420-012-0763-7 
Sabil, F., Abu, H., Kasuma, J., \& Lizzan, N. (2016). Identifying Work-Family Conflict among Nurses : A Qualitative Study. In The European Proceedings of Social \& Behavioural Sciences (pp. 108-120).

Sarkoohijabalbarezi, Z., Ghodousi, A., \& Davaridolatabadi, E. (2017). The relationship between professional autonomy and moral distress among nurses working in children ' $s$ units and pediatric intensive care wards. International Journal of Nursing Sciences, 4, 117-121.

Van Den Tooren, M., \& De Jong, J. (2014). Job demands-resources and employee health and wellbeing. Career Development International, 19(1), 101-122. Doi: 10.1108/CDI-05-2013-0058 